\title{
Studies on Heme Binding in Myoglobin, Hemoglobin, and Cytochrome $c$ by Ion Spray Mass Spectrometry
}

\author{
Y.-T. Li, Y.-L. Hsieh, and J. D. Henion \\ Drug Testing and Toxicology, New York State College of Veterinary Medicine, Cornell University, Ithaca, \\ New York, USA
}

B. Ganem

Department of Chemistry, Baker Laboratory, Cornell University, Ithaca, New York, USA

The ion spray mass spectra of three representative heme-containing proteins were studied, with an emphasis on results obtained under neutral $(\mathrm{pH} \mathrm{7)}$ aqueous conditions. The noncovalently bound heme in myoglobin and hemoglobin may be readily distinguished from the covalently bound heme prosthetic group attached to cytochrome $c$ by using collisioninduced dissociation in the free-jet expansion region of the mass spectrometer as well as in the collision quadrupole with premass selection. The charge state of iron in the expelled heme from myoglobin and hemoglobin appears to be $3+$ but $2+$ for heme expelled from cytochrome c. (J Am Soc Mass Spectrom 1993, 4, 631-637)

\begin{abstract}
$\mathrm{C}$ hanges in protein secondary and tertiary structure that occur in transition from the native to the denatured state often render such macromolecules biologically inactive. Typically, a protein in solution may be partially or completely unfolded by changing the $\mathrm{pH}$, solvent composition, or temperature. Proteins that exhibit such behavior include the hemecontaining proteins hemoglobin, myoglobin, and cytochrome $c$, whose diversity of biological function ranges from oxygen binding to mitochondrial electron transport and oxidative phosphorylation [1, 2].

In myoglobin and hemoglobin, a heme prosthetic group is noncovalently bound in the folds of the polypeptide chain(s), whereas in cytochrome $c$ the heme is covalently attached by two thioether bonds between the protein and the protoporphyrin, as well as coordinate bonds between iron and histidine-18 as well as methionine- 80 . All three proteins have been used as models to examine the effect of electrospray ionization [3-5]. Cytochrome $c$ has also been the subject of recent electrospray mass spectrometry investigations in which the extent of deuteration using $\mathrm{D}_{2} \mathrm{O}$ as a solvent was correlated with overall protein conformation [6a], the extent of denaturation as a function of temperature [6b], and the effect of collision-induced dissociation on different charge states of cytochrome $c$ [6c]. Each of these studies focused on the shift in charge state distribution of the multiply charged ions as a function of
\end{abstract}

Address reprint requests to Jack D. Henion, Drug Testing and Toxicology, New York State College of Veterinary Medicine, Comell University, 925 Warren Drive, Ithaca, NY 14850. solution $\mathrm{pH}_{r}$ solvent conditions, or solution temperature; however, previous studies have placed little emphasis on experimental conditions that effect the expulsion of heme from these proteins. Also, no systematic electrospray results have been reported for these proteins when sprayed from physiologic $\mathrm{pH}$ conditions. We have noted some interesting results with regard to both the charge state of iron in heme expelled from these proteins under electrospray conditions as well as the relative energetics involved in these expulsions.

Recently, we described the use of ion spray mass spectrometry under physiologic conditions to detect and analyze the noncovalent FKBP/FK506 receptor/ drug complex [7], as well as Michaelis complexes of lysozyme with both substrate and products [8]. Others have since reported the ability to detect weak biochemical associations by ion spray mass spectrometry [ 9 , $10]$. In each case, the mild ion evaporation process [11, 12] causes little or no fragmentation, enabling the detection of macromolecular complexes as distinct, gas-phase, noncovalent ions. In an extension of our earlier studies on globins [3] and recent related investigations by others $[4,5,6 \mathrm{~b}, 13,14]$, we report that ion spray mass spectrometry and tandem mass spectrometry (MS/MS) can provide insight into the heme group released from intact myoglobin $(\mathrm{Mb})$, hemoglobin $(\mathrm{Hb})$, and cytochrome $c(\mathrm{Cy})$ at physiologic $\mathrm{pH}$ under controlled experimental conditions. Comparative studies between collision-induced dissociation (CID) in the free-jet expansion region of the atmospheric pressure ionization mass spectrometer (up-front CID) and in the 
central collision cell of the tandem triple quadrupole mass spectrometer provide an indication of the relative binding energies between the protein and the prosthetic group in heme/globin complexes. An interesting observation from this work was the detection of $m / z$ 616 for heme expelled from $\mathrm{Mb}$ and $\mathrm{Hb}$, but $m / z 617$ for heme produced from $\mathrm{Cy}$. We now focus attention on our observations and report studies to rationalize these findings.

\section{Experimental}

\section{Mass Spectrometry}

A Sciex TAGA 6000E atmospheric pressure ionization (API) triple quadrupole mass spectrometer (Thornhill, Ontario, Canada) was updated to an API-III with a scan range to $m / z 2400$. Horse skeletal muscle $\mathrm{Mb}$ [molecular weight (MW) 17,566 Dal, horse $\mathrm{Hb}(\alpha$-chain MW 15,126 Da and $\beta$-chain MW 15,867 Da), and chicken heart $\mathrm{Cy}$ (MW 12,224 Da) were purchased from Sigma Chemical Co. (St. Louis, MO). Each sample $\left(1 \mathrm{mg} / \mathrm{mL}\right.$ in aqueous $10 \mathrm{mM} \mathrm{NH}{ }_{4} \mathrm{OAc}$, $\mathrm{pH} 3$ and 7; no organic solvent) was continuously introduced at $2 \mu \mathrm{L} /$ min at ambient temperature by an infusion pump (Harvard Apparatus, South Natick, MA) for ion spray mass spectrometry and MS/MS experiments. The sprayer was positioned approximately $1 \mathrm{~cm}$ off-axis and $1 \mathrm{~cm}$ away from the ion-sampling orifice and maintained at $3 \mathrm{kV}$ with a flow of nitrogen at 60 $\mathrm{lb} / \mathrm{in}^{2}$ as nebulizing gas. Polypropylene glycol in 80:20 $\mathrm{CH}_{3} \mathrm{CN} / \mathrm{H}_{2} \mathrm{O}$ (3 mM NH $\mathrm{mAC}_{4} \mathrm{OA}$ ) was used for tuning and mass axis calibration for each mass-resolving quadrupole $\left(Q_{1}\right.$ and $\left.Q_{3}\right)$. Single mass spectrometry experiments were performed at declustering potentials of 30,120, and $150 \mathrm{~V}$. Argon collision gas was introduced into the collision cell $\left(Q_{2}\right)$ for the MS/MS experiments, with a collision gas thickness of $300 \times 10^{12}$ atoms $/ \mathrm{cm}^{2}$, a collision energy of $900 \mathrm{eV}$ (laboratory frame), and declustering energy of $30 \mathrm{~V}$. Mass spectra were obtained at a dwell time of $2 \mathrm{~s}$ per scan, with 10 scans summed with a step size of $1 \mathrm{Da}$ or at a step size of $0.05 \mathrm{Da}$ for the accurate measurement of $\mathrm{m} / \mathrm{z} 616$ and 617 .

\section{Results and Discussion}

\section{Mass Spectrometric Measurements at Low $\mathrm{pH}$}

The mass spectra of $\mathrm{Mb}, \mathrm{Hb}$, and $\mathrm{Cy}$ in aqueous 10 $\mathrm{mM} \mathrm{NH}{ }_{4} \mathrm{OAc}$ at $\mathrm{pH} 3$ are shown in Figures 1a, 2a, and $3 a$, respectively. Results for $\mathrm{Mb}$ are consistent with those reported previously by Feng and Konishi [5] (Figure 1a), whereas those for $\mathrm{Hb}$ and $\mathrm{Cy}$ extend the study of heme/globin interactions to additional structures containing both noncovalent $(\mathrm{Hb})$ and covalent (Cy) heme groups. At $\mathrm{pH} \mathrm{3,} \mathrm{the} \mathrm{heme} \mathrm{groups} \mathrm{are}$ known to be completely dissociated from both $\mathrm{Mb}$ and $\mathrm{Hb}$ [15]. Consistent with this fact, the mass spectra at

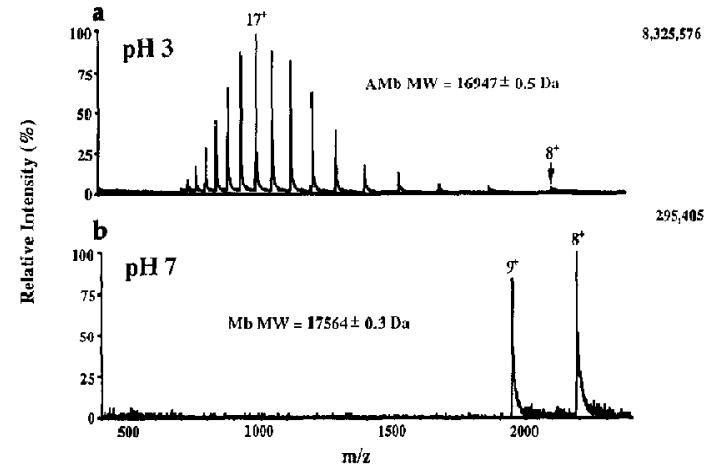

Figure 1. Ion spray mass spectra of $\mathrm{Mb}$ in $10 \mathrm{mM} \mathrm{NH}_{4} \mathrm{OAc}$ buffer at $\mathrm{pH} 3$ (a) versus $\mathrm{pH} 7$ (b) at $30 \mathrm{~V}$ declustering potential. Each spectrum is an averaged sum of 10 scans at a scan rate of 2 $s$ per scan at $2 \mu \mathrm{L} / \mathrm{min}$.

pH 3 display gas-phase ions for apomyoglobin (AMb) and apohemoglobin $(\mathrm{AHb})$ in the $8+$ to $23+$ (Figure 1a) and $7+$ to $20+$ (Figure 2a) charge states, respectively.

$\mathrm{Hb}$ consists of two different heme-containing polypeptide subunits ( $\alpha$ - and $\beta$-chains) that are associated in the native state through hydrogen bonding and hydrophobic interactions into an $\alpha_{2} \beta_{2}$ complex. Mass spectra of $\mathrm{Hb}$ at $\mathrm{pH} 3$ (Figure 2a) reveal overlapping envelopes of multiply protonated, multiply charged $\alpha-\mathrm{AHb}$ and $\beta-\mathrm{AHb}$. Observed MWs $(15,127 \mathrm{Da}$ for $\alpha-\mathrm{AHb} ; 15,868 \mathrm{Da}$ for $\beta-\mathrm{AHb})$ are in good agreement with calculated values ${ }^{1}$ [16].

In contrast to the facile release of heme prosthetic groups when $\mathrm{Mb}$ and $\mathrm{Hb}$ are denatured at low $\mathrm{pH}$, the mass spectrum of $\mathrm{Cy}$ at $\mathrm{pH} 3$ (Figure 3a) indicates that the heme remains attached to the protein even when denatured. Thus, $\mathrm{Cy}$ is denatured, but the heme is not lost. These results suggest that although the

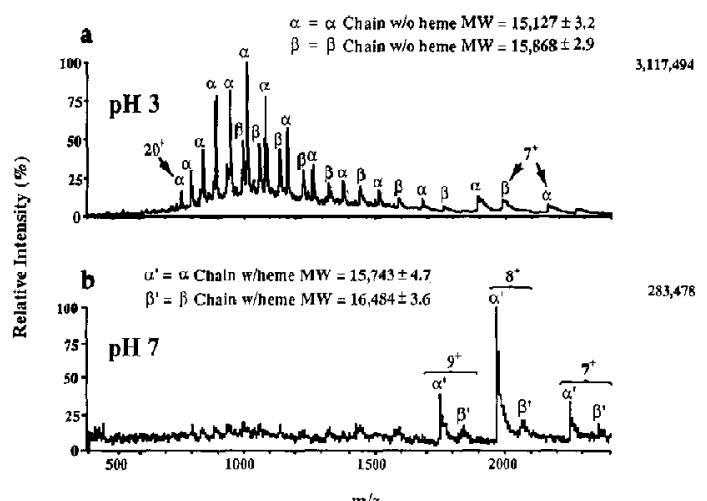

Figure 2. Ion spray mass spectra of $\mathrm{Hb}$ in $10 \mathrm{mM} \mathrm{NH}_{4} \mathrm{OAc}$ buffer at $\mathrm{pH} 3$ (a) versus $\mathrm{pH} 7$ (b) at $30 \mathrm{~V}$ declustering potential. Each spectrum is an averaged sum of 10 scans at a scan rate of 2 s per scan at $2 \mu \mathrm{L} / \mathrm{min}$.

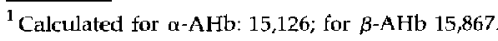




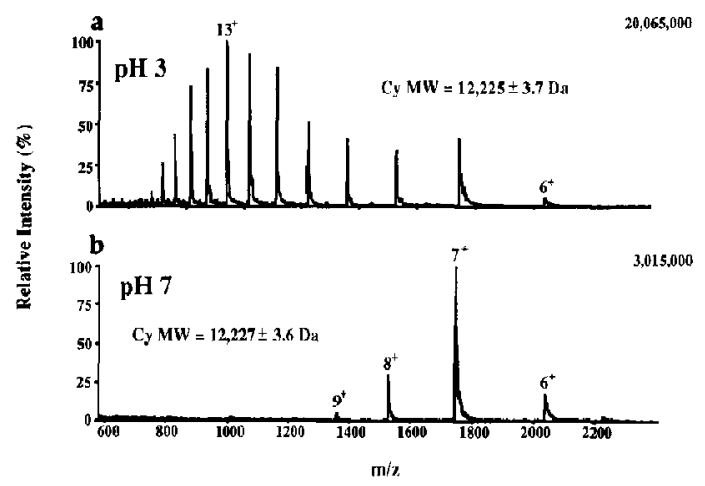

Figure 3. Ion spray mass spectra of $\mathrm{Cy}$ in $10 \mathrm{mM} \mathrm{NH}{ }_{4} \mathrm{OAC}$ buffer at $\mathrm{pH} 3$ (a) versus $\mathrm{pH} 7$ (b) at $30 \mathrm{~V}$ declustering potential. Each spectrum is an averaged sum of 10 scans at a scan rate of 2 s per scan at $2 \mu \mathrm{L} / \mathrm{min}$.

weaker coordination bonds between heme iron and methionine-80 (Met-80) and histidine-18 (His-18) are presumably destroyed at $\mathrm{pH} 3$, the heme prosthetic group is still covalently attached to the $\mathrm{Cy}$ polypeptide through cysteine (Cys)-14 and Cys-17 at this low $\mathrm{pH}$. Experimental (MW 12,227 Da) and calculated (MW $12,224 \mathrm{Da}) \mathrm{MW}$ values are in agreement with this conclusion.

In the course of these studies, we were intrigued by the fact that free heme (MW $616 \mathrm{Da}$ ), which is known to be present when $\mathrm{Mb}$ and $\mathrm{Hb}$ are denatured in aqueous acid [4], could not be detected using mass spectrometry (see Figures 1a and 2a). By contrast, when $\mathrm{Mb}$ was denatured at pI 3 in acetonitrile, a signal at $m / z 616$ (spectrum not shown) was readily observed corresponding to unprotonated $\mathrm{Fe}($ (II)-heme bearing a single positive charge (see below). The apparent effect of solvent on the ability to observe gasphase heme ions is most likely explained by the fact that heme is insoluble in water but soluble in organic solvents [17]. We have shown that extracting aqueous solutions of denatured $\mathrm{Mb}$ or $\mathrm{Hb}$ and redissolving the organic extract in acetonitrile gives rise to a strong signal at $m / z$ 616, corresponding to $\mathrm{Fe}(\mathrm{IIT})$-heme (unpublished results).

\section{Mass Spectrometric Measurements at Neutral $p H$}

In view of earlier success obtaining the ion spray mass spectra of noncovalent drug/receptor complexes at neutral $\mathrm{pH}[7,8]$, we decided to investigate whether native, intact heme/globin complexes might also be observable under the same nonacidic conditions. In fact, the ion spray mass spectrum of $\mathrm{Mb}$ at $\mathrm{pH} 7.0$ (Figure $1 b$ ) shows a major shift in charge state distribution, with no indication of ions corresponding to $\mathrm{AMb}$. The observed $8+$ and $9+$ charge states correspond to an experimentally determined MW of 17,564 , consistent with the structure of $\mathrm{Mb}$ containing the intact noncovalently bound heme (calculated MW $17,566)$. While these experiments were in progress, an independent study by Katta and Chait [4] appeared that demonstrated that $\mathrm{Mb}$ could be observed by conventional electrospray mass spectrometry at $\mathrm{pH} 3.3$ and 3.9. We thus demonstrate that the noncovalent complexes of $\mathrm{Mb}$ may also be detected quantitatively at neutral $\mathrm{pH}$.

We also obtained ion spray mass spectra of intact $\mathrm{Hb}$ at $\mathrm{pH} 7$ (Figure $2 \mathrm{~b}$ ), which displays ions corresponding to the noncovalent complexes of heme with both $\alpha$ - and $\beta$-chains in charge states ranging from $7+$ to $9+$. Again, the experimentally determined MWs for these species are in good agreement with calculated values $^{1}$ [16]; however, all efforts to observe the weaker $\alpha_{2} \beta_{2}$ association of subunits in native $\mathrm{Hb}$ by ion spray mass spectrometry have thus far proved unsuccessful.

For comparison, the ion spray mass spectrum of $\mathrm{Cy}$ was obtained at $\mathrm{pH} 7$ (Figure 3b). As expected, the protein is less extensively protonated under these conditions, and the predicted shift of the charge state distribution results in higher mass-to-charge ratios. A recent report by Chait and co-workers [6b] reported electrospray ionization studies and the thermal denaturation of $\mathrm{Cy}$ at a $\mathrm{pH}$ of 6.6. At a pH of 6.6 and $25^{\circ} \mathrm{C}$. their mass spectrum was similar to ours (Figure $3 b$ ) but had the $8+$ charge state ion as the base peak, whereas at a $\mathrm{pH}$ of 7.0 (Figure $3 \mathrm{~h}$ ) the base peak is the $7+$ ion.

Next, we investigated the conditions required to dislodge the heme prosthetic group from all three proteins studied using CID. When a relatively low 30 $\mathrm{V}$ declustering energy is used in the free-jet expansion region of the mass spectrometer $[7,8,14]$, no fragmentation or loss of the attached heme groups is evident in $\mathrm{Mb}, \mathrm{Hb}$, or $\mathrm{Cy}$ (Figures $1 \mathrm{~b}, 2 \mathrm{~b}, 3 \mathrm{~b}$, respectively); however, when the declustering energy is increased to 120 $\mathrm{V}$, an ion current signal at $m / z 616$ is observed (Figure $4 a, b)$, apparently corresponding to the loss of heme from $\mathrm{Mb}$ and $\mathrm{Hb}$, respectively. Under these conditions, no heme was detected in the mass spectrum of $\mathrm{Cy}$ (Figure $4 \mathrm{c}$ ). Taken as a whole, these results are consistent with the fact that heme groups in $\mathrm{Mb}$ and $\mathrm{Hb}$ interact with their globin protein hosts through relatively weak hydrogen bonding and hydrophobic interactions. By contrast, the heme in $\mathrm{Cy}$ is firmly attached to the protein in Cy by two thioether linkages as well as coordinate bonds between iron and His-18 and Met-80.

\section{Composition of Cas-Phase Heme Ions}

Under higher energy conditions using a declustering energy of $150 \mathrm{~V}$, the heme group in Cy can be dissociated at $\mathrm{pH} 7$ (Figure 5a); however, in these experiments $C y$ produces an ion current signal at $\mathrm{m} / \mathrm{z} 617$ instead of $m / z$ 616. It was of interest to understand why an ion current signal at $m / z 616$ was observed in the facile dissociation of heme from $\mathrm{Mb}$ and $\mathrm{Hb}$ (Figure $4 a, b$ ), whereas the heme released in the decomposition of Cy furnished an ion at $m / z$ 617. The former 

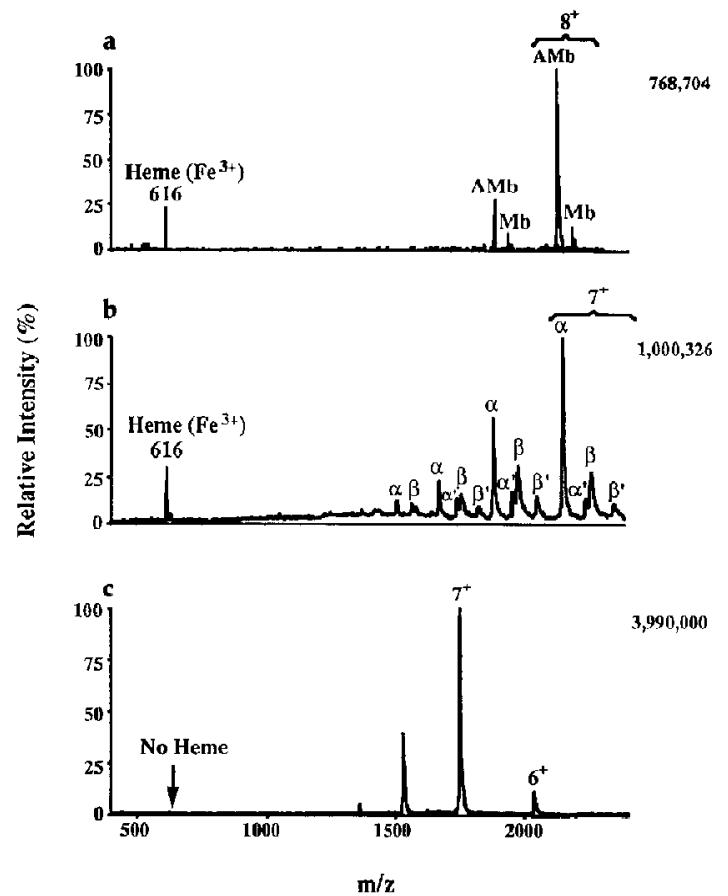

Figure 4. Up-front $\mathrm{CID}$ mass spectra of $\mathrm{Mb}(\mathrm{a}), \mathrm{Hb}(\mathrm{b})$, and $\mathrm{Cy}$ (c) in $10 \mathrm{mM} \mathrm{NH}_{4} \mathrm{OAc}$ buffer ( $\mathrm{pH} 7$ ) at a declustering potential of $120 \mathrm{~V}$. Each spectrum is an averaged sum of 10 scans at a scan rate of $2 \mathrm{~s}$ per scan at $2 \mu \mathrm{L} / \mathrm{min}$.

signal apparently corresponds to Fe(III) or ferric heme, whereas the latter is more consistent with ferrous heme, which is uncharged and requires protonation to be observed at $m / z 617$. The $m / z 616$ ion might correspond to a radical cation, a concept reported recently by Van Berkel et al. [18]. A species like Fe(II), having a relatively low ionization potential, may donate an electron to an available electron acceptor,

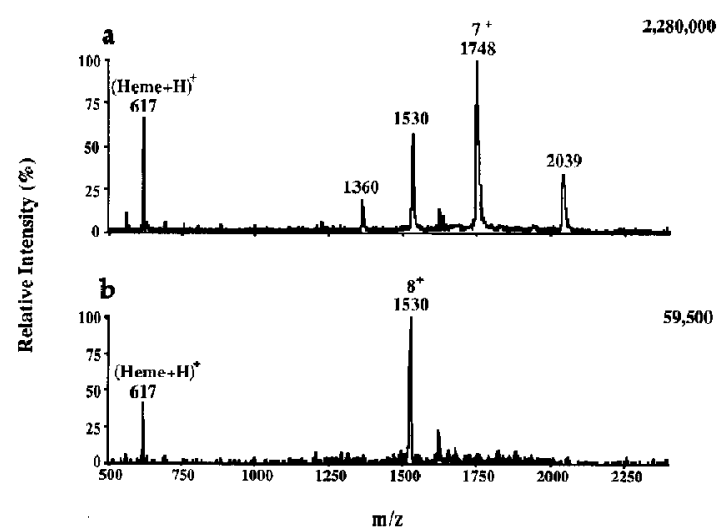

Figure 5. CID mass spectra of $\mathrm{Cy}$ in $10 \mathrm{mM} \mathrm{NH}_{4} \mathrm{OAc}$ buffer $(\mathrm{pH} 7)$ at a declustering potential of $150 \mathrm{~V}$ (a, up-front $\mathrm{CID}$ ) and a collision energy of $1040 \mathrm{eV}$ (b, MS /MS). which in this case could be the electron-deficient, multiply protonated protein. Alternatively, the heme iron in $\mathrm{Mb}$ or $\mathrm{Hb}$ is known to undergo oxidation on exposure to air $^{2}$ [19]. In fact, all commercial samples of $\mathrm{Mb}$ and $\mathrm{Hb}$ that we examined were dark brown in color, the characteristic appearance of oxidized $\mathrm{Mb}$ (ferrimyoglobin) or $\mathrm{Hb}$ (ferrihemnglobin). Even when $\mathrm{Mb}$ was completely reduced [20] under an oxygenfree atmosphere to the red-pink ferrous state (ferromyoglobin) immediately prior to mass spectrometry, sample browning during the ion spray experiment was telltale evidence of concomitant oxidation (unpublished results). Thus, it is likely that the signal at $m / z$ 616 in $\mathrm{Mb}$ and $\mathrm{Hb}$ spectra, whether produced from dissociated heme in solution at $\mathrm{pH} 3$ or by "up-front" CID of heme/globin complex ions in the free-jet expansion region of the spectrometer, is due to very fast air oxidation of the sample, leading to Fe(III)-heme. Prior mass spectrometry studies on $\mathrm{Mb}$ have not, to our knowledge, considered the heme iron charge state and its impact on interpreting its electrospray spectra.

The origin of the signal at $m / z 617$ in the fragmentation of $\mathrm{Cy}$ is less obvious, because two covalent and two coordinate bonds must be broken to release the iron/protoporphyrin complex. Reduction of the iron within the complex may be due to the relatively high electron affinity of metalloporphyrins [18], or may involve electrons available from the "special" electrochemical cell concept of electrospray described by Kebarle and co-workers [21]. Under such high-collision energy conditions, the reduction of metal charge state in electrospray mass spectrometry is also consistent with findings reported by us [22] and others $[23,24]$ in experiments with structures containing easily reducible metal cations.

\section{MS/MS Studies on Gas-Phase Heme / Globin Complexes}

If, as our evidence suggests, the heme ligands in $\mathrm{Mb}$ and $\mathrm{Hb}$ are already oxidized to the ferric state prior to mass spectrometry, this finding bears directly on the interpretation of observed, multiply protonated, gasphase $\mathrm{Mb}$ and $\mathrm{Hb}$ complex ions. Because the oxidized heme prosthetic group bears one positive charge, it should thus contribute to the net charge of the observed heme/globin gas-phase ions, so that an observed charge state of $n+$ in a heme/globin complex ion actually corresponds to protonation of the protein by $n-1$ hydrogen ions. This phenomenon may be important in other electrospray studies of metalloproteins where the metal ion may have differing oxidation states. Further support for this hypothesis may be gained from experiments using ion spray coupled with MS/MS.

\footnotetext{
${ }^{2}$ Heme is well known to undergo rapid air oxidation to the $\mathrm{Fe}^{3+}$ state.
} 
Figure 6a-c summarizes MS/MS studies of the corresponding precursor ions of $\mathrm{Mb}, \mathrm{a}$-chain $\mathrm{Hb}$, and $\mathrm{Cy}$ protonated molecule ions at aqueous $\mathrm{pH} 7$. At $900 \mathrm{-eV}$ collision energy using argon collision gas in the central quadrupole cell of the tandem triple quadrupole mass spectrometer, some of the heme ligands, noncovalently attached to $\mathrm{Mb}$ and $\alpha$-chain $\mathrm{Hb}$, are dissociated from $\mathrm{Mb}$ and the $\alpha$-chain $\mathrm{Hb}$, respectively, whereas no ion current signal is observed for heme from $\mathrm{Cy}$ in Figure 6c. Figure 6a shows the presence of Fe(III)-heme at $m / z 616$ and the remaining undissociated $9+\mathrm{Mb}$ precursor ion. It is noteworthy that the expected $8+$ product ion for $\mathrm{AMb}$ is observed in Figure 6a because its mass-to-charge ratio still lies within the mass range of the mass spectrometer. $\mathrm{CID}$ of the $8+\mathrm{Mb}$ precursor ion did not reveal the $7+$ product ion at $m / z 2508$ because the latter lies outside the mass range of our mass spectrometer (data not shown). In MS / MS studies of multiply charged precursor ions, the sum of the product ion charge states often equals the precursor ion charge state. Thus, in Figure $6 \mathrm{a}$, the $9+\mathrm{Mb}$ precursor ions might be expected to produce the singly charged $\mathrm{Fe}(\mathrm{III})$-heme ion and the $8+\mathrm{AHb}$ ion, as observed in Figure 6a. Figure $6 \mathrm{~b}$ shows the MS/ MS mass spectrum for $\alpha$-chain $\mathrm{Hb}$, which gives the
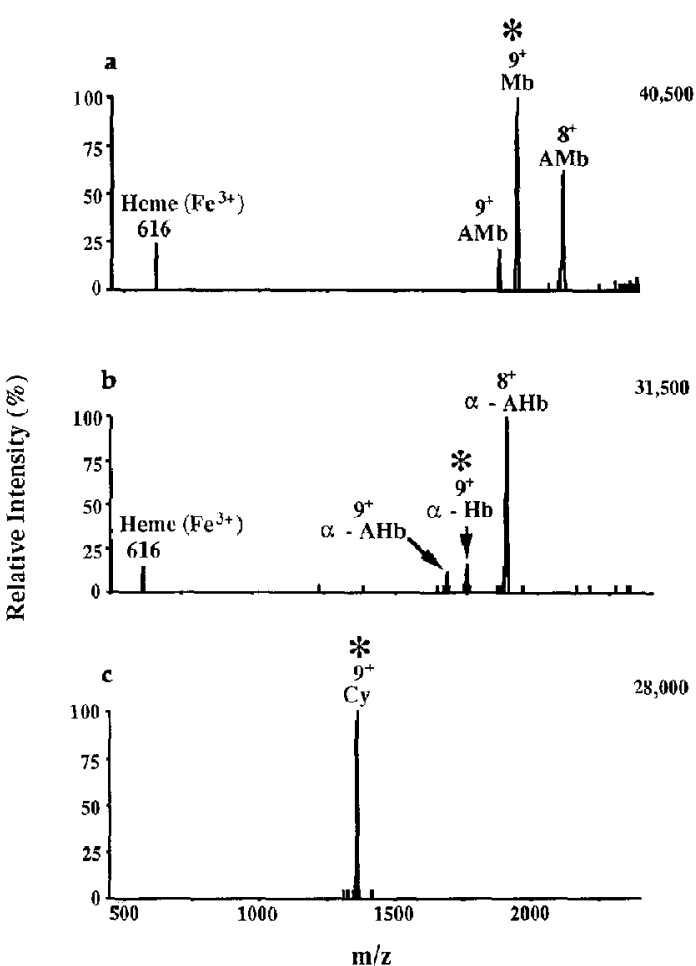

Figure 6. MS/MS mass spectra of Mb (a), $\mathrm{Hb}(\mathrm{b})$, and $\mathrm{Cy}(\mathrm{c})$ in $10 \mathrm{mM} \mathrm{NH}_{4} \mathrm{OAc}$ buffer $(\mathrm{pH} 7)$ at a declustering potential of $30 \mathrm{~V}$ and collision energy of $900 \mathrm{eV}$. The $9+$ charge state of each compound was used as the precursor ion, indicated by * in each case.
Fe(III)-heme at $m / z 616$ and the $8+$ (major) and $9+$ (minor) product ions of $\alpha$-chain $\mathrm{AHb}$, as well as the undissociated $y_{+} \alpha$-chain $\mathrm{Hb}$ precursor ion. Thus for both $\mathrm{Mb}$ and $\mathrm{Hb}$, the dominant dissociation process in MS/MS appears to result in the loss of one positive charge from the complex on dissociation of the cationic heme group. Figure $6 \mathrm{~b}$ offers support in this case for the sum of the product ion charge states totaling the charge state of the precursor ion. It is worth noting, however, that the presence of the $9+\mathrm{AMb}$ and $9+$ $a$-chain $\mathrm{AHb}$ product ions in Figure 6a and b, respectively, suggest that a neutral species may also be lost to produce a product ion of the same charge state as the precursor ion. The absence of any heme observed in Figure $6 \mathrm{c}$ suggests that at this collision energy (900 $\mathrm{eV}$ ), there is insufficient energy to break the stronger covalent bonds holding heme to the polypeptide.

More convincing evidence for differences in the heme product ions derived from $\mathrm{Cy}$ and $\mathrm{Mb}$, for example, is shown in Figures 5 and 7 under aqueous $\mathrm{pH} 7$ conditions. Looking again at Figure 5 we see the full$\operatorname{scan}(m / z$ 500-2400) CID mass spectra for Cy produced from a derlustering energy of $150 \mathrm{~V}$ in the free-jet expansion region (Figure 5a) and the MS/MS spectrum for the $8+$ precursor ion of $\mathrm{Cy}$ obtained at a collision energy of $1040 \mathrm{eV}$ in the central collision cell of the tandem triple quadrupole mass spectrometer (Figure $5 b$ ). These higher energy conditions (see Figure $5 \mathrm{a}$ and $\mathrm{b})$ produce abundant protonated $\mathrm{m} / z$ 617 ions consistent with a heme ion containing $\mathrm{Fe}(\mathrm{II})$ rather than $\mathrm{Fe}(\mathrm{III})$, as observed from $\mathrm{Mb}$ and $\mathrm{Hb}$. Thus, when sufficiently high collision encrgics are used, it is possi ble to break not only the noncovalent and coordinate bonds, but also the covalent bonds in $\mathrm{Cy}$.

Figure $7 a$ and $b$ shows verification of mass assignment for the $m / z 616$ and 617 product ions observed from $\mathrm{Mb}$ and $\mathrm{Cy}$, respectively, under up-front $\mathrm{CID}$ conditions. In these experiments, solutions of each protein were analyzed by ion spray in the same manner as described above with a declustering energy of $150 \mathrm{~V}$ but with the mass spectrometer scanned with a step size of $0.05 \mathrm{Da}$ at unit mass resolution. These mass spectrometric acquisition conditions allow more accurate determination of the mass-to-charge ratio for ions produced under these higher energy collision conditions. Figure $7 a$ shows that a nominal $m / z 616$ is the most abundant ion in the cluster of ions derived from heme dissociated from $\mathrm{Mb}$. The relative abundances of $m / z 617$ and 618 ions observed in Figure $7 \mathrm{a}$ are consistent with those expected for the naturally abundant ${ }^{13} \mathrm{C}$ isotope for heme (calculated $48.6 \%$; observed $50 \%$ for $m / z$ 617). This result is in contrast with a previous report [27] that showed heme at $m / z$ 617 produced from $\mathrm{Mb}$ under heated electrospray conditions using different repeller voltages. Figure $7 \mathbf{b}$ shows the mass-to-charge ratios for heme ions produced from $\mathrm{Cy}$ under $150 \mathrm{~V}$ declustering conditions. Here the most abundant ion in the heme cluster is a nominal $m / z$ 617. Again, the $m / z 618$ and 619 ions 


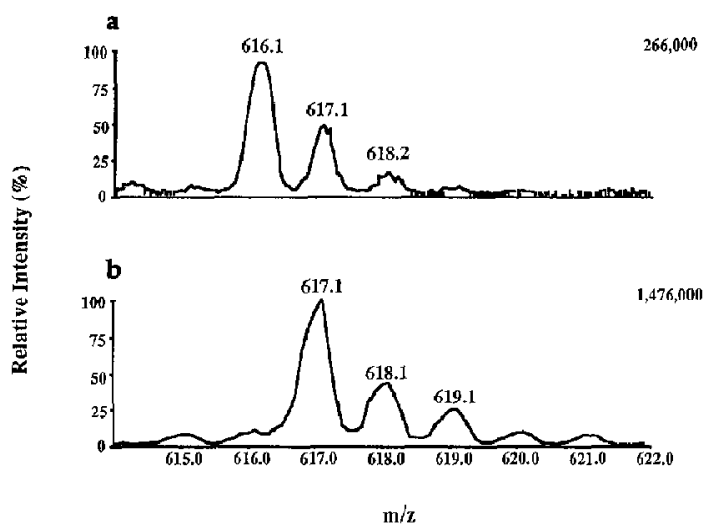

Figure 7. Up-front $\mathrm{CID}$ mass spectra of heme released from $\mathrm{Mb}$ (a) and $\mathrm{Cy}$ (b) in $10 \mathrm{mMNH} \mathrm{NH}_{4} \mathrm{OAc}$ buffer $(\mathrm{pH}$ 7) at a declustering potential of $150 \mathrm{~V}$. Each spectrum is an averaged sum of 32 scans at a scan rate of $2 \mathrm{~s}$ per scan at $2 \mu \mathrm{L} / \mathrm{min}$ with a step size of $0.05 \mathrm{Da}$.

relative abundances are consistent with those expected from naturally abundant ${ }^{13} \mathrm{C}$. These data support the observation that CID produces unprotonated heme at $m / z 616$ from $\mathrm{Mb}$ and $\alpha$-chain $\mathrm{Hb}$, which appears to contain Fe(III), whereas $C y$ produces protonated heme at $m / z 617$, which appears to contain $\mathrm{Fe}$ (II).

\section{Conclusions}

Results from several groups [5, 7-10] have established that isolated, multiply charged, gaseous protein ions are capable of retaining their solution conformational identitics. Such tertiary structure is often essential for the biological specificity manifested by all living systems. Here we show that the ability to observe noncovalent enzyme/substrate [8] and receptor/ligand [7] complexes by ion spray mass spectrometry can be extended to heme/globin complexes that can be delected and analyzed under conditions that closely mimic the physiologic state. Significant differences in the structures of heme/protein complexes may be probed by modulating the experimental conditions (i.e., solvent and $\mathrm{pH}$ ) and also by varying key elements (e.g., declustering and collision energies) of the ion spray mass spectrometer. MS/MS studies of heme/ globin complexes also illustrate how MS/MS may be of value in determining the charge contribution by each component of a noncovalent complex to the net charge observed in the multiply charged, gas-phase complex ions. Recent advances in Fourier transform [13] and magnetic sector mass spectrometers [28] with electrospray ionization capability should allow more precise determination of these factors. Exact mass measurements with these latter technologies as well as deuterium exchange studies [6a] should provide further insight into the contributions to the charge state of ions observed in the mass spectra of these and related compounds. It would appear that much useful information about bound noncovalent states in biological macromolecules may be gained by careful mass spectrometric analysis.

\section{Acknowledgments}

This research was supported by grants from the National Institutes of Health and from the Cornell Biotechnology Program, which is sponsored by the New York State Science and Technology Foundation, a consortium of industries, the US Army Research Office, and the National Science Foundation. We also thank Sciex for partial financial support of this research.

\section{References}

1. Zubay, G. Biochenistry; Addison-Wesley: New York, 1983; Pp. 121-125.

2. Smith, E. L.; Hill, R. L.; Lehman, I. R.; Lefkowitz, R. J.; Hancler, P.; White, A. Principles of Biochemistry; McGraw-Hill: New York, 1983; pp. 27-30, 367-376.

3. Covey, T. R.; Bonner, R. F.; Shushan, B. I.; Henion, J. D. Rapid Commun. Mass Spectrom. 1988, 2, 249-256.

4. Katta, V,; Chait, B. T. J. Am. Chem. Soc. 1991, 113, 8534-8535.

5. Feng, R.; Konishi, Y. Proceedings of the 40th ASMS Conference on Mass Spectrometry and Allied Topics; Washington, DC, May 31-June 5, 1992.

6. (a) Brown, C.; Camilleri, P.; Haskins, N. J.; Saunders, M. J. Chem. Soc. Chem. Commun. 1992, 761-764; (b) Mirza, U. A.; Cohen, S. L.; Chait, B. T. Anal. Chem. 1993, 65, 1-6; (c) Smith, R. D.; Baranaga, C. J.; Udseth, H. R. J. Phys. Chem. 1989, 93, 5019-5022.

7. Ganem, B.; Li, Y. T.; Henion, J. D. J. Am. Chem. Soc. 1991, 113, 6294-6296.

8. Ganem, B.; Li, Y. T; Henion, J. D. I. Am. Chem. Soc. 1991, 113, 78187819.

9. Baca, M.; Kent, S. B. H. J. Am. Chem. Soc. 1992, 114, 3992-3993.

10. Ganuly, A. K.; Pramanik, B. N.; Tsarbopoulos, A.; Covey, T. R.; Huang, E.; Fuhrman, S. A. J. Am. Chem. Soc. 1992, 114, 6559-6560.

11. Fenn, J. B.; Mann, M.; Meng, C. K.; Wong, S. F.; Whitehouse, C. M. Science 1989, 246, 64-71.

12. Bruins, A. P.; Covey, T. R.; Henion, J. D. Anal. Chem. 1987, $59,2642-2646$.

13. Henry, K. D.; Williams, E. R.; Wang, B. H.; McLafferty, F. W.; Shabanowitz, J.; Hunt, D. F. Proc. Natl. Acad. Sci. USA 1989, 86, 9075-9078.

14. Loo, J. A.; Loo, R. R. O.; Goodlett, D. R.; Light-Wahl, K. J.; Edmonds, C. G.; Smith, K. U. Proceedings of the 40th ASMS Conference on Mass Spectrometry and Allied Topics; Washington, DC, May 31-June 5, 1992; p. 7.

15. Breslow, E.; Gurd, Г. R. N. J. Diol. Chem. 1962, 237, 371372.

16. Surber, H. A., Ed. CRC Handbook of Biochemistry; CRC Press: Boca Raton, FL, 1970; p. C248.

17. Weast, R. C., Ed. CRC Handbook of Chemistry and Physics; CRC Press: Boca Raton, FL, 1971; p. C319.

18. Van Berkel, G. J.; McLuckey, S. A.; Glish, G. L. Anal. Chen. 1991, 63, 1098-1109.

19. Stryer, L. Biochemistry, 3rd ed.; Freeman: New York, 1988; Pp. 143-154.

20. Olivas, E.; Waal, D. J. A.; Wilkins, R. G. J. Biol. Chem. 1977, $252,4038-4042$. 
21. Blades, A. T.; Ikonomou, M. G.; Kebarle, P. Anal. Chem. 1991, $63,2109-2114$.

22. Huggins, T. G.; Henion, J. D. Electrophoresis 1993, in press.

23. Blades, A. T.; Jayaweera, P.; Ikonomou, M. G.; Kebarle, P. Int. J. Mass Spectrom. Ion Processes 1990, 102, 251-267.

24. Cheng, Z. L.; Le Blanc, J. C. Y.; Siu, K. W. M.; Guevremont, $\mathrm{R}$; Berman, S. S. Proceedings of the 40th ASMS Conference on Mass Spectrometry and Allied Topics; Washington, DC, May 31-June 5, 1992; pp. 586-587.
25. Lehninger, A. L. Principles of Biochemistry; Worth Publishers: New York, 1982; pp. 150-151.

26. Mortimer, C. E. Chemistry; Van Nostrand: New York, 1979; p. 524 .

27. Allen, M. H.; Vestal, M. L. J. Am. Soc. Mass Spectrom. 1992, 3, $18-26$.

28. Cody, R. B.; Tamura, J.; Musselman, B. D. Anal. Chem. 1992, 64, 1561-1570. 